\title{
Wheat yield and seed physiological quality as influenced by seed vigor, nitrogen fertilization and edaphoclimatic conditions
}

\section{Rendimento de trigo e qualidade fisiológica de sementes influenciados pelo vigor de sementes, adubação nitrogenada e condições edafoclimáticas}

\author{
Diogo Nascimento de Souza'; Sérgio Ricardo Silva²; Jéssica de Lucena \\ Marinho3*; José Henrique Bizzarri Bazzo4; Inês Cristina de Batista Fonseca4; \\ Claudemir Zucareli ${ }^{4}$
}

\section{Highlights}

Vigorous seeds favor wheat crop establishment and productive performance.

BRS Sabiá has higher yield in Ponta Grossa and BRS Gralha-Azul in Londrina.

Nitrogen fertilization increases wheat grain/seed production.

Inadequate $\mathrm{N}$ supply impairs wheat grain and seed production.

\section{Abstract}

Wheat is one of the most important cereals grown in the world, and in Brazil, increasing national production is still a challenge. Nitrogen $(\mathrm{N})$ supply can favor grain yield and the physiological quality of wheat seeds. However, the definition of adequate $\mathrm{N}$ rate and fertilization timing must consider genotype, cultivation environment, and initial seed vigor level. The aim of this work was to evaluate the effect of initial seed vigor and the combinations of rates and timings of $\mathrm{N}$ application on grain yield and seed physiological quality of wheat cultivars under different edaphoclimatic conditions. The experiment was carried out in Londrina and Ponta Grossa, state of Paraná, in a randomized block design in a $2 \times 2 \times 7$ factorial scheme, with four replicates. Treatments consisted of two seed vigor levels (vigorous and non-vigorous seeds), two wheat cultivars (BRS Gralha-Azul and BRS Sabiá) and seven combinations of fertilization timings and N rates (kg $\mathrm{ha}^{-1}$ ) (control-0N; $20 \mathrm{~N}$ at sowing and $60 \mathrm{~N}$ at tillering; $40 \mathrm{~N}$ at sowing; $80 \mathrm{~N}$ at sowing; $40 \mathrm{~N}$ at sowing and $40 \mathrm{~N}$ at tillering; $40 \mathrm{~N}$ at tillering; $80 \mathrm{~N}$ at tillering). Number of emerged seedlings, vegetation index, shoot dry matter, number of fertile spikes $\mathrm{m}^{-2}$ and grain yield were evaluated. Additionally, the physiological potential

1 Agronomist Engineer M.e, Employed in Syngenta Seeds, Maringá, PR, Brazil. E-mail: di.nsouza@gmail.com

2 Researcher, Empresa Brasileira de Pesquisa Agropecuária, EMBRAPA Trigo, Passo Fundo, RS, Brazil. E-mail: sergio. ricardo@embrapa.br

3 Agronomist Engineer, Dra Employed in Jacto, Pompéia, SP, Brazil. E-mail: jlmarinho@live.com

${ }^{4}$ Profs. Drs., Universidade Estadual de Londrina, UEL, Londrina, PR, Brazil. E-mail: josebazzo@uel.br; inescbf@uel.br; claudemircca@uel.br

* Author for correspondence

Received: Mar. 03, 2021 - Approved: Oct. 01, 2021 
of seeds produced in Londrina was evaluated by the testes of first count, germination, seedling emergence in sand and emergence speed index. The climatic conditions during the experiment, in both cultivation environments, were similar to average historical records, with some periods of water deficit. The highest grain yield was obtained with the BRS Gralha-Azul in Londrina, and with BRS Sabiá in Ponta Grossa. The use of vigorous seeds favored the stand establishment and the response of plants to $\mathrm{N}$ fertilization. The treatments $40 \mathrm{~N}+40 \mathrm{~N}$, and $40 \mathrm{~N}+0 \mathrm{~N}$ favored the majority of evaluated variables. Both cultivars showed potential for the production of high physiological potential seeds in Londrina environment. Inadequate $\mathrm{N}$ supply impairs wheat grain yield and seed production.

Key words: Nitrogen rates. Germination. Macronutrient. Seed quality. Triticum aestivum L.

\section{Resumo}

O trigo é um dos cereais mais importantes cultivados no mundo, sendo que no Brasil o aumento da produção nacional ainda é um desafio. A aplicação de nitrogênio (N) pode favorecer o aumento do rendimento de grãos e da qualidade fisiológica de sementes de trigo. Porém, a definição da dose correta de $\mathrm{N}$ e do momento adequado da adubação deve considerar o genótipo, o ambiente de cultivo e o nível de vigor inicial das sementes. O objetivo deste trabalho foi avaliar o efeito do vigor inicial de sementes e de combinações de doses de $\mathrm{N}$ e épocas de adubação sobre o rendimento de grãos e a qualidade fisiológica de sementes de cultivares de trigo em diferentes condições ambientais. O experimento foi conduzido em Londrina e em Ponta Grossa, Paraná, em delineamento em blocos casualizados em esquema fatorial $2 \times 2 \times 7$, com quatro repetições. Os tratamentos consistiram em dois níveis de vigor de sementes (sementes vigorosas e não vigorosas), duas cultivares de trigo (BRS Gralha-Azul e BRS Sabiá) e sete combinações de épocas de adubação e doses de $\mathrm{N}\left(\mathrm{kg} \mathrm{ha}^{-1}\right.$ ) (testemunha-0N; $20 \mathrm{~N}$ na semeadura e $60 \mathrm{~N}$ no perfilhamento; $40 \mathrm{~N}$ na semeadura; $80 \mathrm{~N}$ na semeadura; $40 \mathrm{~N}$ na semeadura e $40 \mathrm{~N}$ no perfilhamento; $40 \mathrm{~N}$ no perfilhamento; $80 \mathrm{~N}$ no perfilhamento). Foram avaliados: número de plântulas emergidas, índice de vegetação, matéria seca da parte aérea, número de espigas $\mathrm{m}^{-2}$ e rendimento de grãos. Adicionalmente, foi avaliado o potencial fisiológico das sementes produzidas em Londrina pelos testes de primeira contagem, germinação, emergência de plântulas em areia e índice de velocidade de emergência. As condições climáticas durante a condução do experimento, em ambos locais de cultivo, foram semelhantes aos registros médios históricos, com alguns períodos de déficit hídrico. O maior rendimento de grãos foi obtido com a BRS Gralha-Azul em Londrina e BRS Sabiá em Ponta Grossa. O uso de sementes vigorosas favoreceu o estabelecimento do estande e a resposta das plantas à fertilização com $\mathrm{N}$. Os tratamentos $40 \mathrm{~N}+40 \mathrm{~N}$ e $40 \mathrm{~N}+0 \mathrm{~N}$ favoreceram a maioria das variáveis avaliadas. Ambas cultivares demostraram potencial para a produção de sementes de elevado potencial fisiológico no ambiente de Londrina. O suprimento inadequado de $\mathrm{N}$ prejudica o rendimento de grãos e a produção de sementes de trigo.

Palavras-chave: Doses de nitrogênio. Germinação. Macronutriente. Qualidade de sementes. Triticum aestivum L. 


\section{Introduction}

Wheat is one of the most important cereals grown in the world, with world production around 766 million tons (United States Department of Agriculture [USDA], 2020). In Brazil, it is the main winter crop and, in the last crop season, wheat production increased by approximately 6.8 million tons, which represents an increase of $32 \%$ compared to the previous crop (Companhia Nacional de Abastecimento [CONAB], 2021). However, Brazilian production is still insufficient to meet domestic consumption, depending on imports to supply approximately half of its demand, which demonstrates the need to expand national production.

Wheat breeding programs in southern Brazil significantly contribute to increase grain production in the country. Increases in wheat grain yield have been observed in recent decades, resulting from the adoption of new cultivars adapted to different environmental conditions, associated with the technified management of the production system (Caierão, Scheeren, Só e Silva, Castro, \& Cargnin, 2013).

Among the various cultivation techniques adopted in order to improve wheat yield, the choice of adapted cultivarsstands out, as genetic characteristics directly influence the growth, development and yield of grains (R. R. Silva et al., 2011). The identification of the best cultivar for each growing environment must consider the genotype $\times$ environment interaction, as there are significant differences in the performance of cultivars when produced under different environmental conditions (Yan \& Holland, 2010). Although wheat presents plasticity of yield components as a function of environmental changes, edaphoclimatic conditions influence gene expression and, therefore, there are specific recommendations of cultivars for each growing region (Tavares, Foloni, Bassoi, \& Prete, 2014).

The use of quality seeds is another fundamental management technique for establishing the crop and obtaining greater grain yield (Abati, Brzezinski, Zucareli, Foloni, \& Henning, 2018). Seed quality is mainly determined by its physiological potential, including seed germination and vigor (Marcos, 2015).

Vigorous seeds present greater germination rate, emergence and initial development, which contributes to a quick and uniform plant stand establishment in the field (Sbrussi \& Zucareli, 2014). On the other hand, low-vigor seeds are less able to withstand adverse environmental conditions, which results in higher proportion of abnormal seedlings and sowing line failures (Henning et al., 2010).

Nitrogen (N) fertilization is also relevant in wheat crop management, as $N$ is the nutrient most uptaken by plants (Pietro-Souza, Bonfim-Silva, Schlichting, \& Silva, 2013), directly influencing their growth, development and productive performance, in addition to be involved in the formation of reserve substances related to the quality of grains and seeds produced (Sangoi, Berns, Almeida, Zanin, \& Schweitzer, 2007).

The high instability of $\mathrm{N}$ forms in tropical and subtropical soils, associated with leaching, volatilization and denitrification processes, becomes it difficult to make this nutrient available to plants and makes $\mathrm{N}$ fertilization complex to manage (Ernani, 2003). In this 
context, splitting $\mathrm{N}$ fertilization is a strategy to make part of the nutrient available at sowing and the rest for topdressing at different phenological crop stages. This strategy can increase the efficiency of $\mathrm{N}$ use by plants and minimize possible leaching losses, which can cause underwater contamination (Costa, Zucareli, \& Riede, 2013; Comissão Brasileira de Pesquisa de Trigo e Triticale [CBPTT], 2016).

Recommendations for $\mathrm{N}$ rates and timings of application should consider the wheat cultivar used, as genotypes differ in terms of tillering capacity, development cycle, plant architecture and production potential. These differences can affect $\mathrm{N}$ use, uptake and assimilation, influencing the quality of the grains and/or seeds produced (Sangoi et al., 2007). Furthermore, the adequate combination of rates and timings of Napplication, depending on the genotype and cultivation environment, can also favor wheat yield components and the quality of the harvested product.

Therefore, the aim of this work was to evaluate the effect of initial seed vigor and the combinations of rates and timings of $\mathrm{N}$ application on grain yield and physiological quality of wheat cultivar seeds produced under different edaphoclimatic conditions.

\section{Material and Methods}

The experiment was carried out in 2015 in two cultivation sites in the state of Paraná, municipalities of Londrina and Ponta Grossa, which have contrasting edaphoclimatic characteristics. In Londrina, the experiment was installed in the experimental farm of Embrapa Soja (23011'37" S and 51011'03" W, and $628 \mathrm{~m}$ a.s.I.), in a clayey-textured Eutroferric Red Latosol. According to the Köppen's classification, the climate is Cfa type, described as humid subtropical with hot summers, infrequent frosts and predominance of rainfalls in the summer months, but without defined dry season. In Ponta Grossa, the experiment was carried out in the experimental farm of Embrapa Produtos e Mercado (2509'31" S and 5004'22" W, and $886 \mathrm{~m}$ a.s.l.), in a medium-textured Dystroferric Red Latosol. The climate is Cfb type, mesothermal humid subtropical, with mild summer, welldistributed rainfall and expressive risk of frost. The maximum, mean, and minimum daily temperatures and rainfall data during the growing season are presented in Figure 1. 

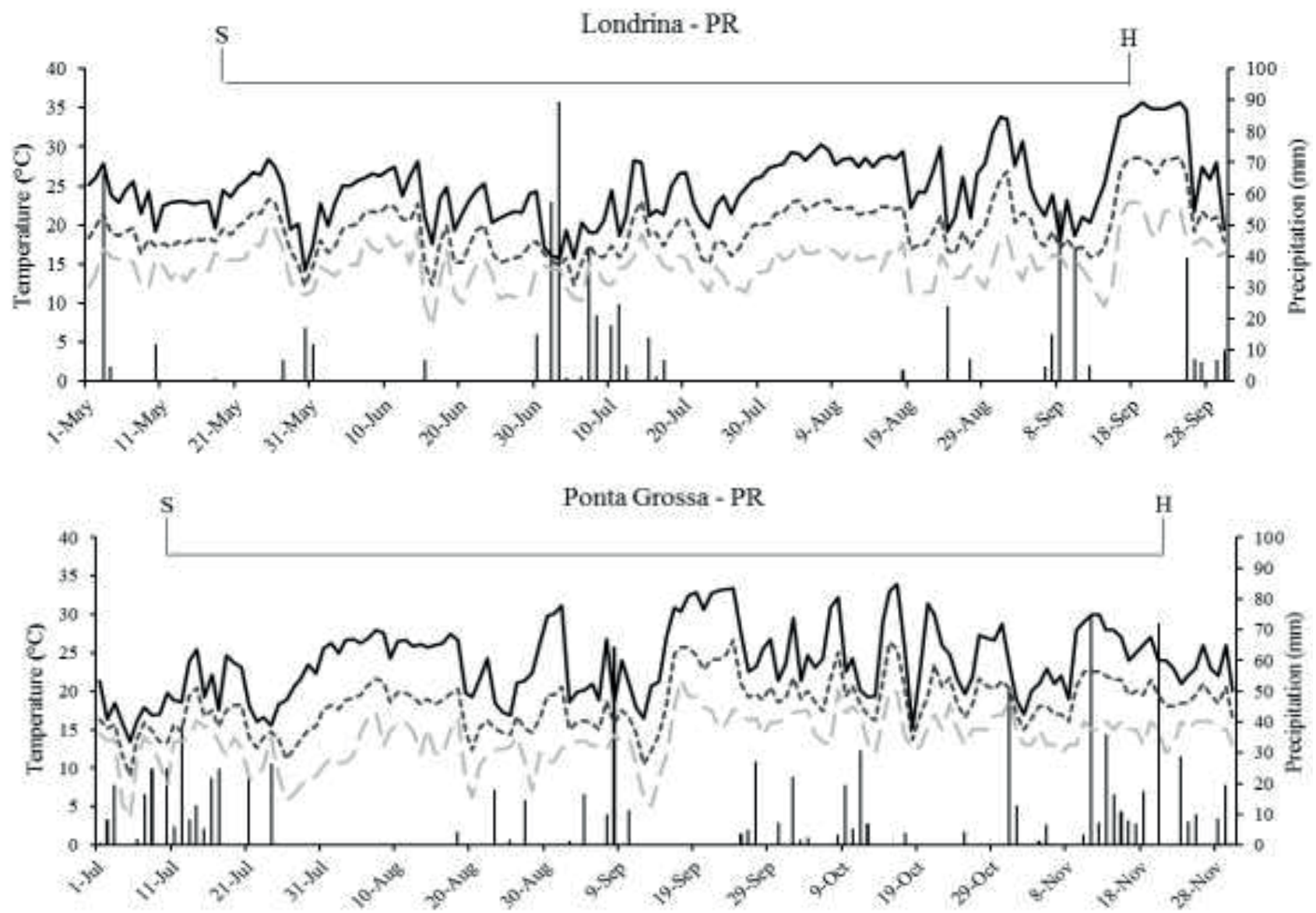

Figure 1. Average daily maximum (-Temp-max), mean (---Temp-mean) and minimum temperature ( - - Temp-min) and precipitation (vertical bars) during the experimental period in Londrina and Ponta Grossa, PR, in the 2015 crop season.

S: sowing; $\mathrm{H}$ : harvesting.

Prior to the installation of the experiment, soil samples were collected in the experimental areas in the 0-20 cm layer for chemical analysis. The results for Londrina and Ponta Grossa were respectively: $\mathrm{pH}$ $\left(\mathrm{H}_{2} \mathrm{O}\right): 5.3$ and 5; $\mathrm{P}$ (Mehlich-1): 31.7 and 10.4 $\mathrm{mg} \mathrm{dm}{ }^{-3} ; \mathrm{H}+\mathrm{Al}: 3.46$ and $4.35 \mathrm{cmol}_{\mathrm{c}} \mathrm{dm}^{-3} ; \mathrm{K}$ : 0.95 and $0.34 \mathrm{cmol}_{\mathrm{c}} \mathrm{dm}^{-3}$; Ca: 4.8 and 3.12 $\mathrm{cmol}_{\mathrm{c}} \mathrm{dm}^{-3}$; $\mathrm{Mg}: 1.87$ and $1.19 \mathrm{cmolc} \mathrm{dm}^{-3}$; CEC: 10.36 and $9 \mathrm{cmol}_{\mathrm{c}} \mathrm{dm}^{-3}$; base saturation (V): 66 and $52 \%$.
The experimental design was completely randomized blocks in a $2 \times 2$ $\times 7$ factorial scheme, with four replicates. Treatments consisted of two wheat cultivars (BRS Gralha-Azul and BRS Sabiá), two initial seed vigor levels (vigorous seeds and nonvigorous seeds) and seven combinations of timings of application and $\mathrm{N}$ rates $\left(\mathrm{kg} \mathrm{ha}^{-1}\right)$ (control-0N; $20 \mathrm{~N}$ at sowing and $60 \mathrm{~N}$ at tillering; $40 \mathrm{~N}$ at sowing; $80 \mathrm{~N}$ at sowing; $40 \mathrm{~N}$ at sowing and $40 \mathrm{~N}$ at tillering; $40 \mathrm{~N}$ at tillering; $80 \mathrm{~N}$ at tillering). 
BRS Sabiá is a bread class wheat cultivar with early cycle, stability for industrial quality and grain yield, wide adaptability, rapid initial establishment, lower tillering capacity and can be sown at any time as long as recommended for the crop (Bassoi \& Foloni, 2015a; Bassoi et al., 2019). BRS Gralha-Azul is a bread/improver class wheat with medium cycle, it is stable for industrial quality, with wide adaptability and better tillering capacity (Bassoi \& Foloni, 2015b; Bassoi et al., 2019).

Seeds considered to have lower vigor were obtained from lots of vigorous seeds using a process of vigor reduction through accelerated artificial aging, which consisted of packaging seeds in gerbox-type plastic boxes, with screened supports, containing $40 \mathrm{~mL}$ of distilled water, and subsequent incubation in BOD chamber at temperature of $42{ }^{\circ} \mathrm{C}$ for a period of 48 hours. After this process, aged and non-aged seeds were exposed to environment with controlled temperature and humidity for humidity homogenization. Seeds not submitted (vigorous) and those submitted to the artificial vigor reduction process (lower vigor) did not receive any treatment with fungicides or insecticides, and were characterized (Table 1) for initial physiological quality by the following tests:

\section{Table 1}

Physiological attributes of vigorous and non-vigorous seeds of BRS Gralha-Azul and BRS Sabiá cultivars used in the sowing of the experiment

\begin{tabular}{ccccc|} 
Vigor level & \multicolumn{5}{c}{ Physiological attributes } \\
\cline { 2 - 5 } & FG (\%) & G (\%) & SE (\%) & ESI \\
Vigorous & 91 & \multicolumn{2}{c|}{ BRS Gralha-Azul } \\
Non-vigorous & 74 & 96 & 86 & 12.81 \\
& & 88 & 78 & 11.61 \\
Vigorous & 91 & 97 & BRS Sabiá & 12.97 \\
Non-vigorous & 87 & 95 & 77 & 11.75 \\
\hline
\end{tabular}

FG: first germination count; G: germination; SE: seedling emergence in sand; ESI: emergence speed index.

Germination: carried out with eight subsamples of 50 seeds distributed on germination paper moistened with volume of distilled water in the proportion of 2.5 times the dry mass of the substrate. Paper rolls with seeds were placed in BOD at temperature of $20^{\circ} \mathrm{C}$. Evaluations of normal seedlings were carried out at four (first count) and eight days (final count) after the test installation and the results expressed as percentage (Ministério da Agricultura, Pecuária e Abastecimento [MAPA], 2009).

Seedling emergence in sand: carried out in greenhouse with four replicates of 50 seeds sown at depth of $4 \mathrm{~cm}$ in trays containing washed sand. Periodic irrigations were carried out to maintain humidity. The number of normal seedlings was evaluated on the fifteenth day after sowing and results were expressed as percentage. 
Emergence speed index: performed in combination with the seedling emergence in sand test by means of daily counts of the number of normal emerged seedlings, without discarding them, obtaining a cumulative value. Collected data were used to calculate the emergency speed index according to formula proposed by Maguire (1962).

Experiments were carried out in a notillage system in area previously occupied with soybean crop. Experimental areas were separated by at least $100 \mathrm{~m}$ from other wheat crops. Based on the chemical soil characteristics in experimental areas, base fertilization was carried out in the sowing furrow, using $250 \mathrm{~kg} \mathrm{ha}^{-1}$ of 00-20-20 formulated fertilizer $\left(\mathrm{N}-\mathrm{P}_{2} \mathrm{O}_{5}-\mathrm{K}_{2} \mathrm{O}\right)$. The first split $\mathrm{N}$ fertilization in top dressing was performed on the day of sowing, and the second split was carried out in the same way at the beginning of the tillering stage, using ammonium nitrate as source of N. Cultural practices were performed as needed, according to indications of the Brazilian Commission for Wheat and Triticale Research for wheat crop (S. R. Silva, Bassoi, \& Foloni, 2018). Roughing activity was carried out when necessary in order to guarantee the genetic purity of cultivars.

Seeds with high degree of purity, provided by the genetic breeder of wheat cultivars, were used. Sowing was carried out with 350 viable seeds per $\mathrm{m}^{-2}$ on May 18 and July 7, 2015, in Londrina and Ponta Grossa, $\mathrm{PR}$, respectively, according to indication of the climatic risk agricultural zoning (ZARC) for each municipality (MAPA, 2015). Seeds were treated with insecticide (imidacloprid) and fungicide (carboxin + thiram) prior to sowing. Experimental plots were formed by 10 rows with 6 meters in length spaced 0.20 $\mathrm{m}$. For evaluations, the 6 central rows were considered as useful area, discarding $0.5 \mathrm{~m}$ at the initial and final ends of the plot.

Harvesting was carried out after grains/ seeds reached harvest maturity, a stage characterized by caryopsis hardening, plants with dry appearance and grains/seeds with moisture content below 20\%. Immediately after harvest, $2 \mathrm{~kg}$ of grains/seeds (with moisture content of 14-15\%) were sampled from each experimental plot to carry out analyses of wheat productive performance and physiological quality of seeds. Samples were air-dried until reaching approximately $13 \%$ humidity, and then kept in cold chamber $\left(7-10^{\circ} \mathrm{C}\right)$ until analyses.

To determine the productive performance of wheat, the following evaluations were carried out in both cultivation environments:

Number of emerged seedlings per $\mathrm{m}^{-2}$ : performed fifteen days after sowing by counting the total number emerged seedlings in an area of $0.75 \mathrm{~m}^{2}$ per plot, which is composed of three sub-samples of $0.25 \mathrm{~m}^{2}$.

Normalized Difference Vegetation Index(NDVI): evaluatedusing the GreenSeeker ${ }^{\circledR}$ equipment during the stem elongation growth stage (Zadoks GS 30). The device was positioned approximately $30 \mathrm{~cm}$ above the canopy of plants, traversing the useful area of the experimental plot at constant speed.

Shoot dry matter (SDM): evaluated at the physiological maturity stage of grains (Zadoks GS 92) through sampling in two $0.5 \mathrm{~m}$ long crop rows, totaling $0.2 \mathrm{~m}^{2}$ per experimental plot. Sampled plants were cut close to the soil surface, and the plant material was dried in oven with forced air circulation at $60^{\circ} \mathrm{C}$ until reaching constant weight. Subsequently, all material and also the grains were weighted 
separately. SDM was obtained by subtracting the grain weight from the total weight of plants.

Number of fertile spikes $\mathrm{m}^{-2}$ : quantified at the harvest maturity stage, by counting the total number of fertile spikes within the sampled area $\left(0.25 \mathrm{~m}^{2}\right)$.

Grain yield: determined by harvesting grain from plants contained in the useful area of the plot. After threshing, grains were weighed and data were transformed into $\mathrm{kg}$ ha ${ }^{-1}$ at $13 \%$ moisture content.

The physiological quality of seeds produced by both cultivars in the experiment of Londrina was evaluated through first count tests, germination, seedling emergence in sand, and emergence speed index, according to methods previously described. The physiological potential of seeds produced in Ponta Grossa was not evaluated, as there was no production of 'seeds', since the germination percentage was below the standard $(\leq 80 \%)$ established for the seed commercialization in both cultivars (MAPA, 2013).

Data obtained were submitted to analysis of normality and homogeneity of deviations and, later, to analysis of variance. Means of cultivars and vigor levels were compared by the $\mathrm{F}$ test and of combinations of rates and timings of $\mathrm{N}$ application by the Scott-Knott test, all at 5\% significance using the R software (R Core Team [R], 2020).

\section{Results and Discussion}

\section{Agronomic characteristics and yield components}

The 'cultivar' factor influenced the following characteristics: emerged seedlings,
NDVI (only in Londrina), grain yield, SDM and number of fertile spikes $\mathrm{m}^{-2}$ (Table 2). For most of variables, BRS Sabiá cultivar presented superior performance in relation to BRS Gralha-Azul, except for grain yield in Londrina.

The difference in cultivar behavior is mainly related to edaphoclimatic and genetic characteristics, which determine the length of the development cycle, formation of yield components, ability to adapt to cultivation environments, and length of the maturation period (Iwańska, Paderewski, Stepień, \& Rodrigues, 2020). The highest grain yield of the BRS Gralha-Azul in Londrina shows its better adjustment capacity and compensation of some yield components.

The number of emerged seedlings in Londrina was influenced by the initial seed vigor level, with the highest values for vigorous seeds (Table 2). This result corroborates Rossi, Cavariani and França (2017), who studied the effect of seed vigor on soybean agronomic performance and found that vigorous seeds favored some crop characteristics, especially the initial seedling development, without necessarily influencing final yield. Working with wheat, Abati et al. (2018) also observed that high-vigor seeds favored stand establishment, plant growth and development at early phenological stages, in addition to grain yield. In Ponta Grossa, milder temperatures and higher rainfall during the initial phase of crop establishment allowed seeds with less vigor to emerge in a similar way as those with greater vigor, demonstrating an environmental compensation effect.

Despite inconsistencies in literature on the influence of seed vigor on grain yield, the use of vigorous seeds anticipates the initial crop establishment, with higher proportion of 
normal seedlings, emergence uniformity and plant development (Amaro et al., 2014) and, therefore, should be recommended.

The combinations of rates and timings of N application influenced SDM and NDVI (only in Ponta Grossa) (Table 2). The application of 40 $\mathrm{kg} \mathrm{ha}^{-1}$ of $\mathrm{N}$ at sowing favored SDM in Londrina, being this treatment superior to the others. In Ponta Grossa, the application of $80 \mathrm{~kg} \mathrm{ha}^{-1}$ of $\mathrm{N}$ at the beginning of tillering resulted in higher SDM, while the control treatment (without $\mathrm{N}$ fertilization) resulted in the worst result. For NDVI evaluated in Ponta Grossa, 40N + ON, $80 \mathrm{~N}+0 \mathrm{~N}$, and $40 \mathrm{~N}+40 \mathrm{~N}$ treatments stood out compared to the others.

Nitrogen is one of the most important nutrients for the wheat crop, as it is an essential constituent of the cell wall, chlorophyll, nucleic acids and important biomolecules such as ATP, NADH and NADPH, and participates in key metabolic pathways and reactions essential for plant survival (Taiz, Zeiger, Moller, \& Murphy, 2017). Furthermore, $N$ fertilization directly influences the leaf area index of plants, which improves the efficiency of solar radiation use and results in greater biomass production (Heinemann et al., 2006). Therefore, increase in SDM and NDVI in treatments with $\mathrm{N}$ compared to control treatment (without addition of $\mathrm{N})$, regardless of cultivation environment, confirms the importance of this nutrient for wheat.

The production of SDM in Londrina was also influenced by the interaction between cultivar and seed vigor (Table 2). When originated from non-vigorous seeds, BRS Gralha-Azul plants produced $14 \%$ more SDM than BRS Sabiá plants. On the other hand, when originated from vigorous seeds, there was no difference between cultivars regarding SDM. Regarding the vigor effect individually for each cultivar, it was verified that BRS Gralha-Azul plants from non-vigorous seeds produced greater amount of SDM $(12,031 \mathrm{~kg}$ $\left.\mathrm{ha}^{-1}\right)$ compared to vigorous seeds $(11,182 \mathrm{~kg}$ $\left.\mathrm{ha}^{-1}\right)$, which effect was not observed for BRS Sabiá plants (data not shown). 


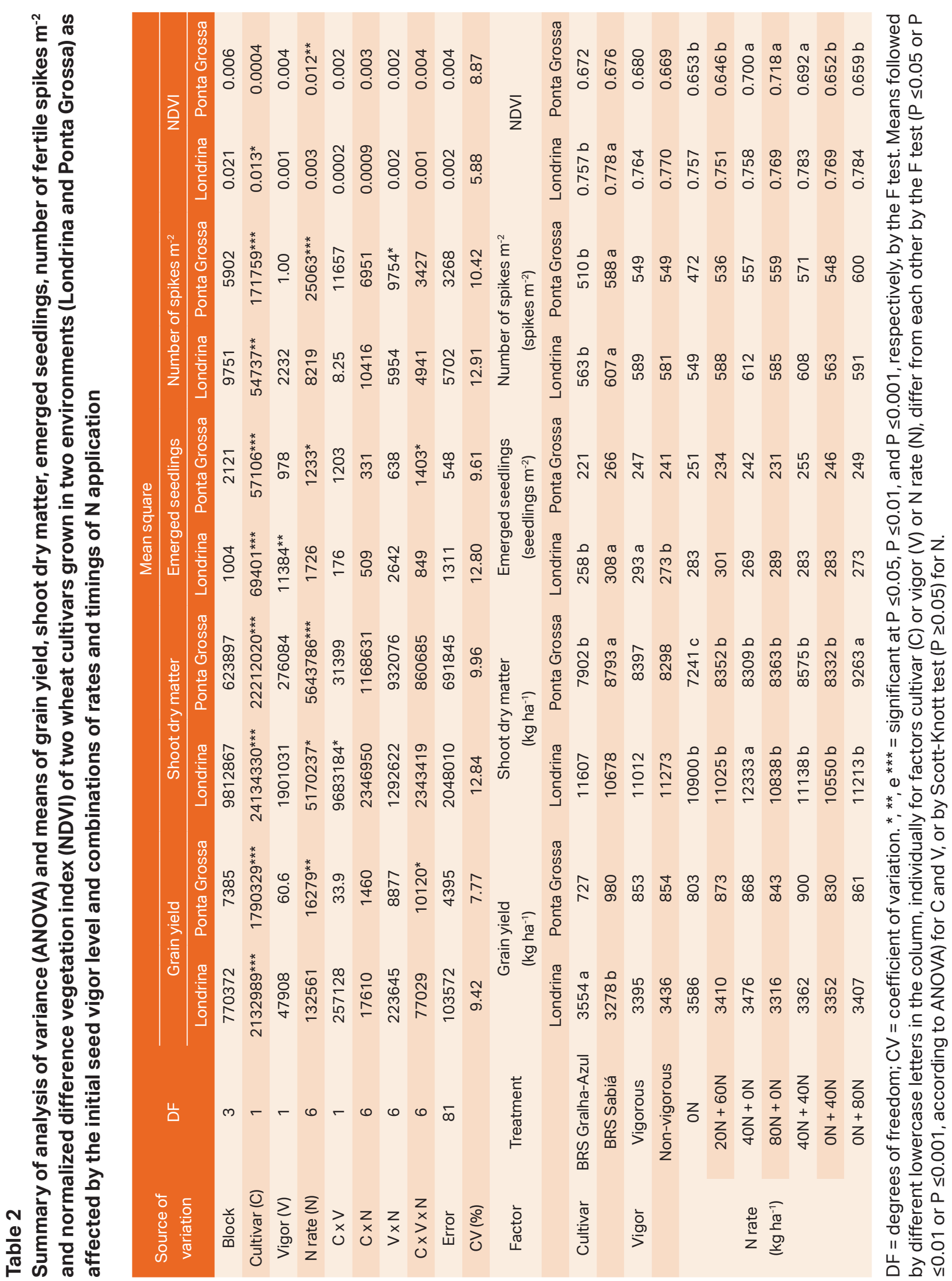


The differences observed in the performance of cultivars are due to the expression of the respective genetic characteristics, which include the tillering capacity in different cultivation environments (Abati et al., 2018). BRS Gralha-Azul showed greater adaptability in relation to BRS Sabiá, as it produced large amounts of SDM even for plants obtained from non-vigorous seeds. This may be related to the greater tillering capacity of this cultivar (Bassoi \& Foloni, 2015b; Bassoi et al., 2019), reflecting in the increase of the number of spikes per area, minimizing the effects of low vigor on grain yield.

The interaction between combinations of rates and timings of $\mathrm{N}$ application with seed vigor was significant for the number of fertile spikes $\mathrm{m}^{-2}$ in Ponta Grossa (Table 2). For plants originating from vigorous seeds, $40 \mathrm{~N}+$ $40 \mathrm{~N}$, and $\mathrm{ON}+80 \mathrm{~N}$ treatments favored spike production. On the other hand, treatment without $\mathrm{N}$ application resulted in the lowest production of spikes $\mathrm{m}^{-2}$. For plants originating from non-vigorous seeds, most combinations of rates and timings of $\mathrm{N}$ application were favorable to spike production, except for treatments without $\mathrm{N}$ fertilization and $20 \mathrm{~N}+$ $60 N$. Regarding vigor level, there was difference only in $40 \mathrm{~N}+\mathrm{ON}$ treatment, with superiority of plants originating from non-vigorous seeds in relation to those from vigorous seeds. In the other combinations of rates and timings of $\mathrm{N}$ application, no significant differences were observed between initial seed vigor levels (data not shown).

Nitrogen application favors the tillering of the wheat plant and, consequently, increases the density of fertile spikes per area, as verified in the present work. On the other hand, $\mathrm{N}$ deficiency in Poaceas, such as wheat, can negatively affect the formation of leaves and tillers (Neumann, Oliveira, Spada, Figueira, \& Poczynek, 2009), which influences the number of fertile spikes $\mathrm{m}^{-2}$, as seen in the control treatment (without addition of $\mathrm{N}$ ), which often reduces grain yield.

Effect of the cultivar $x$ vigor $x$ combination of rate and timing of $\mathrm{N}$ application for the variables grain yield and emerged seedlings was observed, both evaluated in Ponta Grossa (Table 2), whose results are shown in Table 3.

For grain yield in Ponta Grossa, no difference was observed between seed vigor levels for BRS Gralha-Azul. For BRS Sabiá, difference in $0 \mathrm{~N}$ and $20 \mathrm{~N}+60 \mathrm{~N}$ treatments was observed, with vigorous seeds being superior in the control treatment, and nonvigorous seeds being superior in the $20 \mathrm{~N}+$ $60 \mathrm{~N}$ treatment. As for combinations of rates and timings of $\mathrm{N}$ application, no significant difference in grain yield was observed among treatments for plants originating from vigorous seeds of both cultivars evaluated. For plants originating from non-vigorous seeds, $40 \mathrm{~N}$ $+\mathrm{ON}$ and $40 \mathrm{~N}+40 \mathrm{~N}$ treatments resulted in higher grain yield for BRS Gralha-Azul. For BRS Sabiá, all treatments favored the yield of plants originating from non-vigorous seeds, except for treatment without $\mathrm{N}$ application. Assessing the effect of cultivar, individually for each seed vigor level, greater grain yield of BRS Sabiá in relation to BRS Gralha-Azul was observed in all treatments, regardless of vigor of seeds that originated the wheat crop (Table 3). 


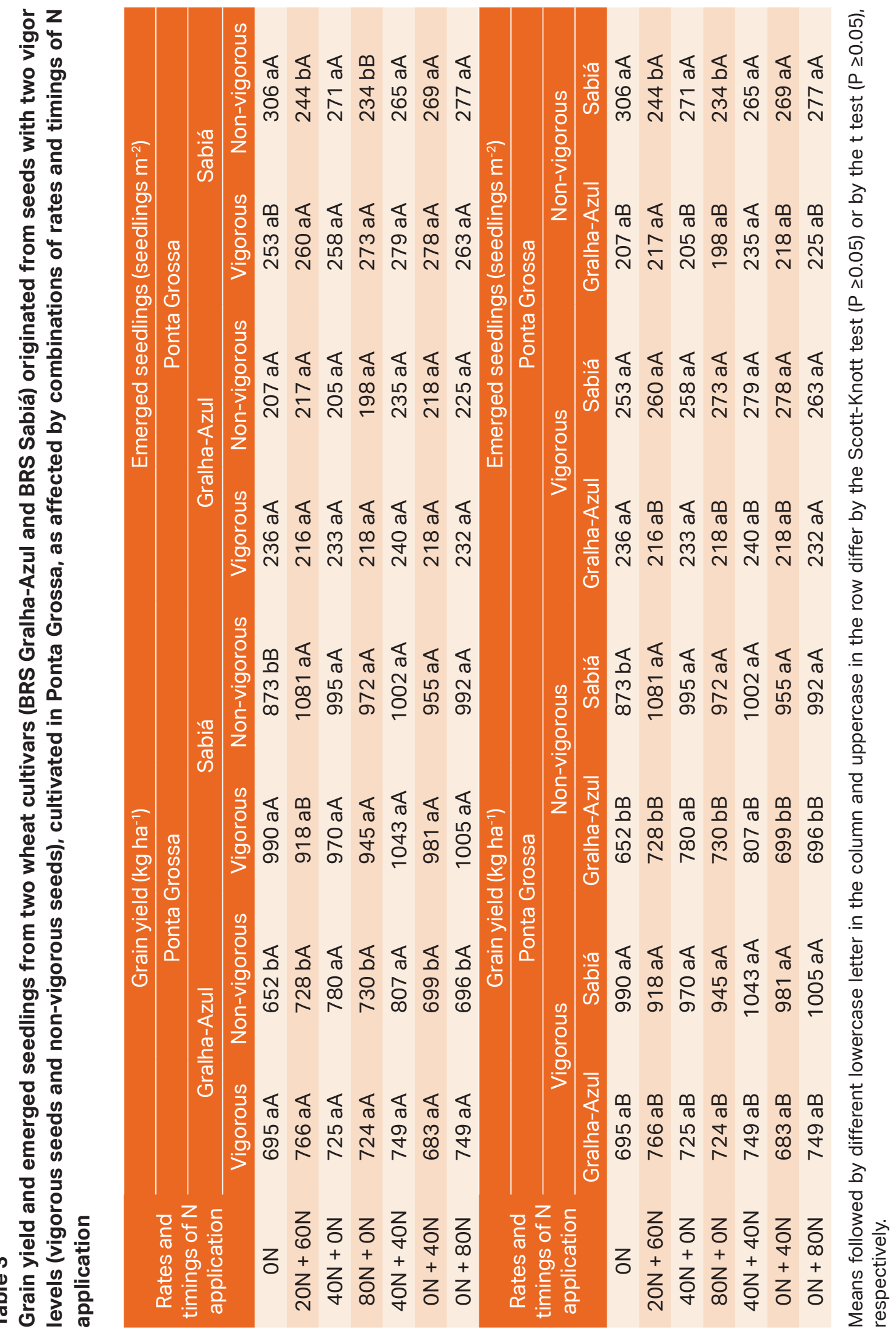


For the 'emerged seedlings' characteristic in Ponta Grossa, no significant difference was found comparing the seed vigor levels for the BRS Gralha-Azul. For BRS Sabiá, difference in emerged seedlings in the control treatment was observed, with better performance of non-vigorous seeds, and in the $80 \mathrm{~N}+0 \mathrm{~N}$ treatment, with superiority of vigorous seeds. Regarding N combinations, no significant difference was observed among treatments for BRS Gralha-Azul in both vigor levels evaluated, and for BRS Sabiá originated from vigorous seeds. For plants originated from non-vigorous seeds of BRS Sabiá, most treatments favored the number of emerged plants $\mathrm{m}^{-2}$, except for the application of $20 \mathrm{~kg} \mathrm{ha}^{-1}$ of $\mathrm{N}$ at sowing +60 $\mathrm{kg} \mathrm{ha}^{-1}$ of $\mathrm{N}$ at tillering and $80 \mathrm{~kg} \mathrm{ha}^{-1}$ of $\mathrm{N}$ at sowing, which resulted in the lowest emerged seedlings value. Difference was also observed between cultivars for the number of emerged seedlings in Ponta Grossa, at both vigor levels evaluated, with BRS Sabiá being superior to BRS Gralha-Azul in most of the $\mathrm{N}$ fertilization combinations, except for plants originated from vigorous seeds in $0 \mathrm{~N}, 40 \mathrm{~N}+0 \mathrm{~N}$, and $\mathrm{ON}+80 \mathrm{~N}$ treatments, in which no significant differences were observed between cultivars (Table 3).

The little significant influence of the initial seed vigor level for cultivars under study shows that both have high adaptability, as even plants originated from non-vigorous seeds showed grain yield similar to those from vigorous seeds. In addition to the ability of compensation among yield components, reasonable meteorological conditions, with few periods of water deficit (Figure 1), also justify the low magnitude of difference between vigor levels, since the effects of vigor on wheat establishment and yield is more accentuated under more unfavorable environmental conditions (Marcos, 2015).

For treatments with $\mathrm{N}$ fertilization, it was observed that $\mathrm{N}$ availability favored the productive performance of the wheat crop. $\mathrm{N}$ application of $40 \mathrm{~kg} \mathrm{ha}^{-1}$ at sowing and topdressing at the beginning of tillering or only at sowing $(40 \mathrm{~N}+40 \mathrm{~N}$, and $40 \mathrm{~N}+\mathrm{ON}$ treatments, respectively) favored most of the evaluated variables, regardless of vigor and cultivar. These results confirm that adequate $\mathrm{N}$ availability is essential for growth, development and high yield of wheat grains (Mattuella et al., 2018).

On the other hand, in the absence of $\mathrm{N}$ (ON treatment), cultivars showed lower performance for most variables under study, showing that the deficiency of this nutrient is harmful to the development and yield of wheat grains. Camponogara, Oliveira, Georgin and Rosa (2016) studied the effect of $\mathrm{N}$ fertilization on the wheat productive performance and also found that treatments that included $\mathrm{N}$ application were superior to control treatment (without N).

Although the application of a single $\mathrm{N}$ rate $\left(80 \mathrm{~kg} \mathrm{ha}^{-1}\right)$ at sowing or topdressing has favored, to a lesser extent, wheat cultivars, this management should be avoided due to the risks associated with the application of high $\mathrm{N}$ rates, which increase $\mathrm{N}$ losses and can cause underwater contamination. Furthermore, the application of high $\mathrm{N}$ rates can cause plant lodging and, consequently, hamper mechanized harvesting and reduce grain yield and quality (Teixeira, Buzetti, Andreotti, Arf, \& Benett, 2010). Therefore, splitting $\mathrm{N}$ fertilization, by providing part of 
$\mathrm{N}$ in sowing and other part in topdressing, is the most recommended management, as this nutrient is considered to have high mobility in soil. Haile, Nigussie and Ayana (2012) studied rates and timings of $\mathrm{N}$ application in wheat and found that splitting $\mathrm{N}$ fertilization increased grain yield, corroborating results obtained in the present work.

In general, BRS Sabiá stood out over BRS Gralha-Azul, as it was more responsive to $\mathrm{N}$ fertilization, especially in the Ponta Grossa environment. However, it is important to highlight that $\mathrm{N}$ application favored the performance of both cultivars. Benin et al. (2012) studied the response of wheat cultivars to $\mathrm{N}$ rates and obtained response variability between cultivars; however, $\mathrm{N}$ fertilization favored yield components of all genotypes.

The most favorable results to $\mathrm{N}$ application in Ponta Grossa can be attributed to the milder temperatures in this region (Figure 1), which results in slower rates of soil organic matter mineralization and decomposition of straw from the previous crop, which reduces the $\mathrm{N}$ supply. In Londrina, on the other hand, temperatures are higher and, therefore, there are greater rates of mineralization and decomposition, which may increase $\mathrm{N}$ availability for wheat plants. Thus, $\mathrm{N}$ is uptaken in greater amounts by plants through these pathways, reducing the possibility of crop response to $\mathrm{N}$ fertilization. Thus, in Londrina, there is no such strong response to $\mathrm{N}$ fertilization as in Ponta Grossa.

\section{Physiological potential of seeds}

In Londrina, there was no significant effect of factors on variable seedling emergence in sand (Table 4). However, there were interactions between cultivar $\times$ vigor, and between $\mathrm{N}$ fertilization $\times$ vigor on seed germination.

Regarding germination, BRS Sabiá was $3 \%$ higher than BRS Gralha-Azul, only for seeds originated from crops using nonvigorous seeds (Table 4). Plants from vigorous seeds of BRS Gralha-Azul produced seeds with higher germination (in relation to those from non-vigorous seeds), which can be attributed to the better development of plants during the growth cycle and to the greater accumulation of photoassimilates that, translocated to reproductive organs, contributed to the formation of seeds with greater amount of reserve substances. For BRS Sabiá, no significant difference in germination was observed, comparing seed vigor levels. Concerning $\mathrm{N}$ fertilization treatments, no difference was observed among them, considering non-vigorous seeds (Table 5). On the other hand, plants from vigorous seeds produced seeds with higher germination in $40 \mathrm{~N}+\mathrm{ON}, 80 \mathrm{~N}+\mathrm{ON}$, and $\mathrm{ON}$ $+80 \mathrm{~N}$ treatments. Significant difference was also observed between initial seed vigor levels in $\mathrm{ON}, 40 \mathrm{~N}+\mathrm{ON}$, and $\mathrm{ON}+80 \mathrm{~N}$ treatments, with better performance of vigorous seeds (over non-vigorous seeds) (data not shown), whose result can be attributed to better plant development, greater accumulation of photoassimilates and better quality of the formed seeds, as previously discussed. It is important to highlight that treatments presented germination above $80 \%$, that is, above the minimum value established for commercialization of wheat seeds (MAPA, 2013). 


\section{Table 4}

Summary of analysis of variance (ANOVA) and means of first count, germination, seedling emergence in sand, and emergence speed index of two wheat cultivars, cultivated in Londrina, as affected by the initial seed vigor level and combinations of rates and timings of $\mathrm{N}$ application

\begin{tabular}{|c|c|c|c|c|c|}
\hline \multirow{3}{*}{$\begin{array}{l}\text { Source of } \\
\text { variation }\end{array}$} & \multirow{3}{*}{ DF } & \multicolumn{4}{|c|}{ Mean square } \\
\hline & & \multicolumn{4}{|c|}{ Londrina } \\
\hline & & First count & Germination & $\begin{array}{l}\text { Seedling } \\
\text { emergence }\end{array}$ & $\begin{array}{l}\text { Emergence } \\
\text { speed index }\end{array}$ \\
\hline Block & 3 & 23.7 & 10.1 & 27.3 & 0.25 \\
\hline Cultivar (C) & 1 & 0.76 & $63.6^{*}$ & 60.0 & $9.74^{* *}$ \\
\hline Vigor (V) & 1 & $94.4^{*}$ & $45.8^{*}$ & 26.0 & 0.014 \\
\hline $\mathrm{N}$ rate & 6 & 29.3 & $25.3^{*}$ & 10.6 & 0.24 \\
\hline $\mathrm{C} \times \mathrm{V}$ & 1 & $71.0^{*}$ & $76.2^{* *}$ & 15.8 & 0.17 \\
\hline $\mathrm{C} \times \mathrm{N}$ & 6 & $89.7^{* * *}$ & 17.6 & 18.6 & 0.32 \\
\hline $\mathrm{V} \times \mathrm{N}$ & 6 & $117^{* * *}$ & $44.0^{* *}$ & 54.6 & 0.65 \\
\hline $\mathrm{C} \times \mathrm{V} \times \mathrm{N}$ & 6 & $42.5^{*}$ & 9.79 & 57.0 & $2.55^{*}$ \\
\hline Error & 81 & 16.7 & 10.6 & 30.5 & 0.99 \\
\hline CV (\%) & & 4.67 & 3.55 & 6.19 & 10.6 \\
\hline Factor & Treatment & $\begin{array}{l}\text { First count } \\
\text { (\%) }\end{array}$ & $\begin{array}{c}\text { Germination } \\
\text { (\%) }\end{array}$ & $\begin{array}{c}\text { Seedling } \\
\text { emergence (\%) }\end{array}$ & $\begin{array}{l}\text { Emergence } \\
\text { speed index }\end{array}$ \\
\hline \multirow{2}{*}{ Cultivar (C) } & BRS Gralha-Azul & 88 & 91 & 88 & 9.14 \\
\hline & BRS Sabiá & 88 & 92 & 90 & 9.73 \\
\hline \multirow{2}{*}{ Vigor (V) } & Vigorous & 89 & 92 & 90 & 9.45 \\
\hline & Non-vigorous & 87 & 91 & 89 & 9.43 \\
\hline \multirow{7}{*}{$\begin{array}{l}\text { N rate } \\
\left(\mathrm{kg} \mathrm{ha}^{-1}\right)\end{array}$} & $\mathrm{ON}$ & 88 & 90 & 89 & 9.38 \\
\hline & $20 N+60 N$ & 87 & 92 & 89 & 9.45 \\
\hline & $40 N+0 N$ & 88 & 92 & 90 & 9.60 \\
\hline & $80 N+0 N$ & 88 & 93 & 89 & 9.45 \\
\hline & $40 N+40 N$ & 87 & 91 & 88 & 9.42 \\
\hline & $\mathrm{ON}+40 \mathrm{~N}$ & 87 & 91 & 89 & 9.56 \\
\hline & $O N+80 N$ & 90 & 93 & 90 & 9.23 \\
\hline
\end{tabular}

$\mathrm{DF}=$ degrees of freedom; $\mathrm{CV}=$ coefficient of variation. ${ }^{*}{ }^{* *}, \mathrm{e}^{* * *}=$ significant at $\mathrm{P} \leq 0.05, \mathrm{P} \leq 0.01$, and $\mathrm{P} \leq 0.001$, respectively, by the $\mathrm{F}$ test. 


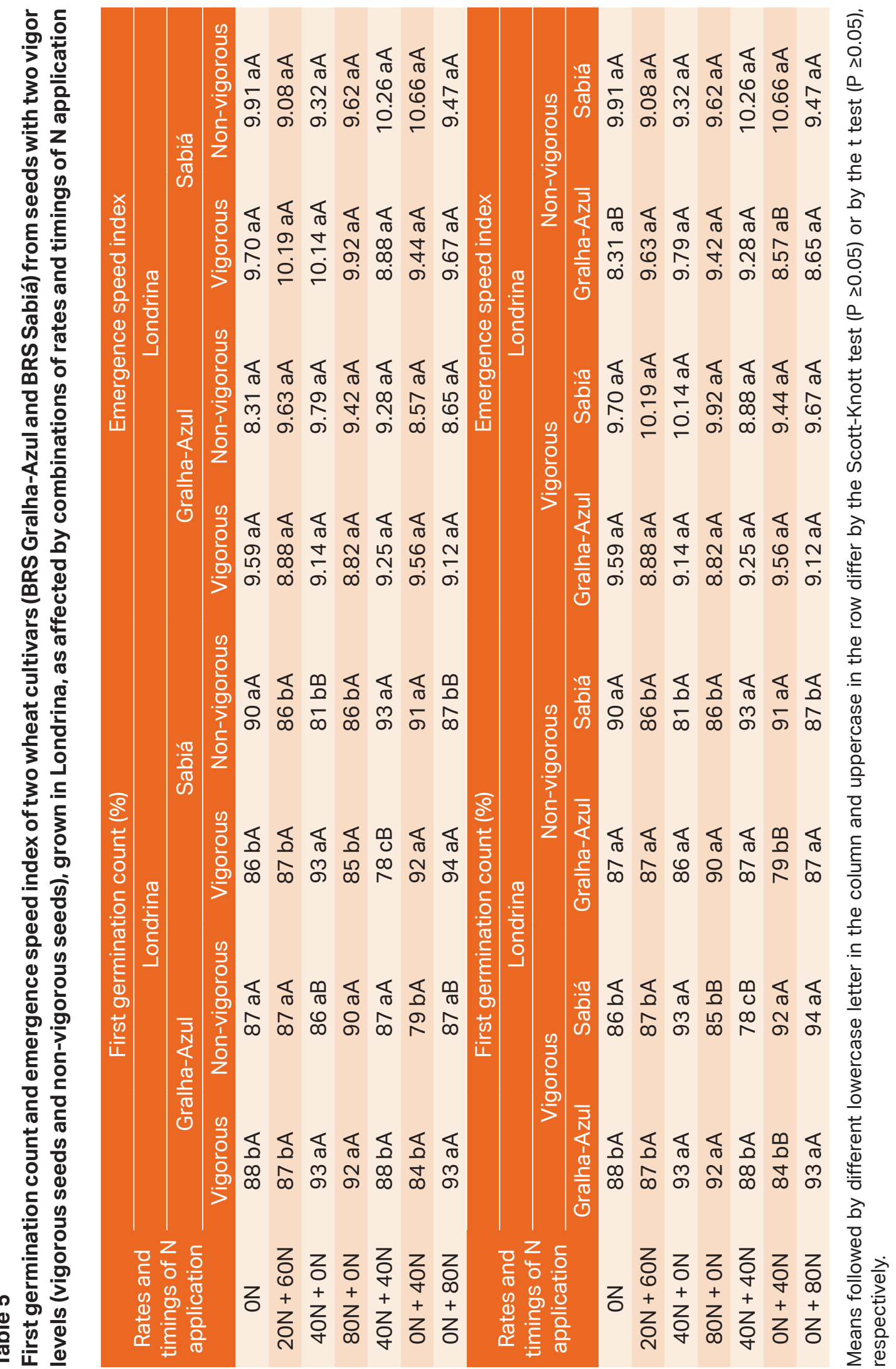


The results obtained reinforce the argument that the use of vigorous seeds is essentialtoguaranteeseedling emergenceand development, especially under unfavorable conditions, in addition to provide greater possibility of reaching the desired plant stand (Marcos, 2015), reflecting in greater production of better quality seeds. Furthermore, vigorous seeds generated vigorous plants that were more responsive to $\mathrm{N}$ fertilization. Marinho et al. (2021) studied the effects of initial seed vigor on the performance of two wheat cultivars under different edaphoclimatic conditions and found that vigorous seeds favored stand establishment, especially under unfavorable environmental conditions, which directly influences crop performance.

The interaction between cultivar $x$ vigor $\times$ combination of rate and timing of $\mathrm{N}$ application was significant for the variables 'first germination count' and 'emergence speed index' (Table 4).

For the first germination count, difference between vigor levels in $40 \mathrm{~N}+0 \mathrm{~N}$, and $\mathrm{ON}+80 \mathrm{~N}$ treatments was observed, with superiority of vigorous seeds for both cultivars (Table 5). Furthermore, for BRS Sabiá, difference was also found between vigor levels in $40 \mathrm{~N}+40 \mathrm{~N}$ treatment, in which lowvigor seeds were superior to vigorous ones.

Regarding combinations of rates and timings of $\mathrm{N}$ application, BRS Gralha-Azul seeds originated from vigorous seeds showed higher germination speed (first count) in $40 \mathrm{~N}$ $+\mathrm{ON}, 80 \mathrm{~N}+\mathrm{ON}$, and $\mathrm{ON}+80 \mathrm{~N}$ treatments (Table 5). For seeds from crops originated from non-vigorous BRS Gralha-Azul seeds, most treatments with $\mathrm{N}$ fertilization (except for $\mathrm{ON}+40 \mathrm{~N}$ ) favored the first germination count, as the $\mathrm{N}$ supply increases the grain protein content (Lollato, Jaenisch, \& Silva,
2021), which is an important substance used by seeds during the germination process. For BRS Sabiá, seeds from crops originated from vigorous seeds showed better performance in $40 \mathrm{~N}+0 \mathrm{~N}, \mathrm{ON}+40 \mathrm{~N}$, and $\mathrm{ON}+80 \mathrm{~N}$ treatments, while seeds derived from non-vigorous seeds were superior in $0 \mathrm{~N}, 40 \mathrm{~N}+40 \mathrm{~N}$, and $\mathrm{ON}+40 \mathrm{~N}$ treatments. Significant difference was also observed between cultivars in $80 \mathrm{~N}+0 \mathrm{~N}$, and $40 \mathrm{~N}+40 \mathrm{~N}$ treatments for vigorous seeds with BRS Gralha-Azul being superior to BRS Sabiá - and in $0 N+40 N$ treatment for seeds of both vigor levels, with superiority of BRS Sabiá over BRS Gralha-Azul (Table 5).

For the emergence speed index, significant difference between cultivars originated from crops formed by non-vigorous seeds in $\mathrm{ON}$ and $\mathrm{ON}+40 \mathrm{~N}$ treatments was observed, with better emergence speed performance of seeds produced by BRS Sabiá (Table 5). In the other treatments, there was no significant difference between cultivars.

Despite the difference observed between cultivars in some treatments, both showed high physiological performance of seeds, demonstrating their adaptation to the region of Londrina.

The results obtained for the physiological performance of seeds indicate that most combinations that include $\mathrm{N}$ fertilization favored the evaluated characteristics, with the exception of $20 \mathrm{~N}+$ $60 \mathrm{~N}$ treatment, for both cultivars. Nitrogen uptaken by plants during the crop cycle can increase the protein content in the produced seeds (Lollato et al., 2021). The proteins of seeds are essential for the initial seedling establishment, as they undergo hydrolysis during the germination process in order to meet the nutritional demand of the embryo (Carvalho \& Nakagawa, 2012). Therefore, it 
is important to provide plants with adequate $\mathrm{N}$ nutrition, as well-nourished plants tend to produce better quality seeds.

Finally, the results reinforce that the use of vigorous seeds is important for the establishment of wheat crops, as they favor seedling emergence and development even under unfavorable conditions (Marcos, 2015; Abati et al., 2018), avoiding costly operations of reseeding and allowing the use of lower seeding density. In addition, the use of vigorous seeds in the crop establishment reflects on the yield and quality of the final product. Bazzo et al. (2021) studied the effects of initial seed vigor on plant performance and wheat seed production and observed that seeds from plants established with high-vigor seeds had higher physiological quality, corroborating results obtained in this study.

\section{Conclusions}

The use of vigorous seeds favors the quick and uniform plant stand establishment, originates vigorous plants that are more responsive to $\mathrm{N}$ fertilization, and contributes to improving grain yield and the production of better quality wheat seeds.

Nitrogen fertilization favors grain yield and physiological performance of wheat seeds in both cultivation environments, regardless of vigor level and cultivar used.

BRS Gralha-Azul provides greater grain yield in Londrina, and BRS Sabiá in Ponta Grossa. Both cultivars have potential for wheat seed production in Londrina, with germination above the commercialization standards for this cereal. Inadequate $\mathrm{N}$ supply reduces wheat productive performance and the physiological potential of the produced seeds.

\section{References}

Abati, J., Brzezinski, C. R., Zucareli, C., Foloni, J. S. S., \& Henning, F. A. (2018). Growth and yield of wheat in response to seed vigor and sowing densities. Revista Caatinga, 31(4), 891-899. doi: 10.1590/ 1983-21252018v31n411rc

Amaro, H. T. R., David, A. M. S. S., Silva, I. C., Neta, Assis, M. O., Araújo, E. F., \& Araújo, R. F. (2014). Teste de envelhecimento acelerado em sementes de crambe (Crambe abyssinica Hochst), cultivar FMS Brilhante. Revista Ceres, 61(2), 202208. doi: 10.1590/S0034-737X2014000 200007

Bassoi, M. C., \& Foloni, J. S. S. (2015a). Cultivar de trigo BRS Sabiá: características e desempenho agronômico. Londrina: EMBRAPA Soja. Recuperado de https:// ainfo.cnptia.embrapa.br/digital/ bitstream/ item/124123/1/comunicado-tecnico-84Sabia-OL.pdf

Bassoi, M. C., \& Foloni, J. S. S. (2015b). Cultivar de trigo BRS Gralha-Azul: características e desempenho agronômico. Londrina: EMBRAPA Soja. Recuperado de https:// ainfo.cnptia.embrapa.br/digital/ bitstream/ item/124119/1/comunicado-tecnico-82Gralha-OL1.pdf

Bassoi, M. C., Riede, C. R., Campos, L. A. C., Foloni, J. S. S., Nascimento, A., Jr., Arruda, K. M. A., \& Silva, S. R. (2019). Cultivares de trigo e triticale BRS e IPR - EMBRAPA e IAPAR. Londrina: EMBRAPA Soja. Recuperado de https://www.infoteca. cnptia.embrapa.br/infoteca/bitstream/ doc/1108 376/1/Catalogotrigo20191.pdf 
Bazzo, J. H. B., Garcia, E. B., Marinho, J. L., Gomes, D., Silva, S. R., \& Zucareli, C. (2021). Vigor de sementes e adubação nitrogenada na produtividade e na qualidade fisiológica de sementes de trigo. Revista Cultura Agronômica, 30(1), 39-50. doi: 10.32929/2446-8355.2021v3 On1p39-50

Benin, G., Bornhofen, E., Beche, E., Pagliosa, E. S., Silva, C. L., \& Pinnow, C. (2012). Agronomic performance of wheat cultivars in response to nitrogen fertilization levels. Acta Scientiarum. Agronomy, 34(3), 275-283. doi: 10.1590/ S1807-86212012000300007

Caierão, E., Scheeren, P. L., Só e Silva, M., Castro, R. L. de, \& Cargnin, A. (2013). Uso do germoplasma da EMBRAPA nos programas de melhoramento de trigo no Brasil. Ciência Rural, 44(1), 57-63. doi: 10.15 90/S0103-84782013005000144

Camponogara, A. S., Oliveira, G. A., Georgin, J., \& Rosa, A. L. D. (2016). Avaliação dos componentes de rendimento do trigo quando submetido a diferentes fontes de nitrogênio. Revista Eletrônica em Gestão, Educação e Tecnologia Ambiental, 20(1), 524-532. doi: 105902/2236117019723

Carvalho, N. M., \& Nakagawa, J. (2012). Sementes: ciência, tecnologia e produção (5a ed.). Jaboticabal: FUNEP.

Comissão Brasileira de Pesquisa de Trigo e Triticale (2016). Informações técnicas para trigo e triticale: safra 2016. Brasília: EMBRAPA.

Companhia Nacional de Abastecimento (2021). Acompanhamento da safra brasileira de grãos: Safra 2020/21. Brasília: Ministério da Agricultura, Pecuária e Abastecimento.
Costa, L., Zucareli, C., \& Riede, C. R. (2013). Parcelamento da adubação nitrogenada no desempenho produtivo de genótipos de trigo. Revista Ciência Agronômica, 44(2), 215-224. doi: 10.1590/S1806-669 02013000200002

Ernani, P. R. (2003). Disponibilidade de nitrogênio e adubação nitrogenada para macieira. Lages: Graphel.

Haile, D., Nigussie, D., \& Ayana, A. (2012). Nitrogen use efficiency of bread wheat: effects of nitrogen rate and time of application. Journal of Soil Science and Plant Nutrition, 12(3), 389-409. doi: 10.4067/S071 8-95162012005000002

Heinemann, A. B., Stone, L. F., Didonet, A. D., Trindade, M. G., Soares, B. B., Moreira, J. A. A., \& Cánovas, A. D. (2006). Eficiência de uso da radiação solar na produtividade do trigo decorrente da adubação nitrogenada. Revista Brasileira de Engenharia Agrícola e Ambiental, 10(2), 352-356. doi: 10. 1590/S1415-43 662006000200015

Henning, F. A., Mertz, L. M., Jacob, E. A., Jr., Dorneles, R. M., Fiss, G., \& Dejalma, P. Z. (2010). Composição química e mobilização de reservas em sementes de soja de alto e baixo vigor. Bragantia, 69(3), 727-733. doi: 10.1590/S0006-87 052010000300026

Iwańska, M., Paderewski, J., Stepień, M., \& Rodrigues, P. C. (2020). Adaptation of winter wheat cultivars to different environments: a case study in Poland. Agronomy, 10(5), 1-20. doi: 10.3390/ agronomy 10050632

Lollato, R. P., Jaenisch, B. R., \& Silva, S. R. (2021). Genotype-specific nitrogen uptake 
dynamics and fertilizer management explain contrasting wheat protein concentration. Crop Science, 61(3), 1-19. doi: $10.1002 / c s c 2.20442$

Maguire, J. D. (1962). Speed of germination-aid in selection and evaluation for seedling emergence and vigor. Crop Science, 2(1), 176-177. doi: 10.2135/cropsci1962.0011 183X000200020033x

Marcos, J., Fo. (2015). Fisiologia de sementes de plantas cultivadas (2a ed.). Londrina: ABRATES.

Marinho, J. L., Silva, S. R., Souza, D. N., Fonseca, I. C. B., Bazzo, J. H. B., \& Zucareli, C. (2021). Wheat yield and seed physiological quality affected by initial seed vigor, sowing density, and environmental conditions. Semina: Ciências Agrárias, 42(3), 1595-1614. doi: 10.5433/1679-0359.2021v42n3Supl1 p1595

Mattuella, D., Simioni, S. P., Segatto, C., Cigel, C., Adams, C. R., Klein, C.,... Sordi, A. (2018). Eficiência agronômica da cultura do trigo submetida a doses de nitrogênio em diferentes estádios ontogênicos. Ciência Agrícola, 16(3), 1-9. doi: 10.28998/rca.v16 i3.5176

Ministério da Agricultura, Pecuária e Abastecimento (2009). Regras para análise de sementes. Brasília: MAPA/ACS. Recuperado de http://www.agricultura. gov.br/assuntos/laboratorios/arquivospublicacoeslaboratorio/regras-paraanalise-de-sementes.pdf/view

Ministério da Agricultura, Pecuária e Abastecimento (2013). Instrução Normativa $n^{\circ} 45$ de 2013. Secretaria de
DefesaAgropecuária.Brasília:MAPA/DAS/ CSM. Recuperado dehttp://www.abrasem. com.br/wp-content/uploads/2012/10/ Instru\%C3\%A7\%C3\%A3o-Normativan\%C2\%BA-45-de-17-de-Setembrod e - 2013 - Padr\% C $3 \%$ B 5 e s - de Identidade-e-Qualiidade-Prod-eComerc-de-Sementes-Grandes-Culturas-Republica\%C3\%A7\%C3\%A3oDOU-20.09.13.pdf

Ministério da Agricultura, Pecuária e Abastecimento (2015). SISZARC Sistema de zoneamento agrícola de risco climático. Brasília: MAPA. Recuperado de http://sistemasweb. agricultura.gov.br/siszarc/gerarRelatorio RelacaoCultivares.action?sgJAASAplic acaoPrincipal=siszarc

Neumann, M., Oliveira, M. R., Spada, C. A., Figueira, D. N., \& Poczynek, M. (2009). Componentes de rendimento e produção da planta de cevada em função de níveis de adubação nitrogenada em cobertura. Pesquisa Aplicada e Agrotecnologia, 2(3), 61-68. doi: 10.5777/paet.v2i3.1504

Pietro-Souza, W., Bonfim-Silva, E. M., Schlichting, A. F., \& Silva, M. C. (2013). Desenvolvimento inicial de trigo sob doses de nitrogênio em Latossolo Vermelho de Cerrado. Revista Brasileira de Engenharia Agrícola e Ambiental, 17(6), 575-580. doi: 10.1590/S1415-436 62013000600001

R Core Team (2020). R: A language and environment for statistical computing. Vienna: $R$ Foundation for Statistical Computing. Retrieved from https:// www.R-project.org/ 
Rossi, R. F., Cavariani, C., \& França, J. de B., Neto. (2017). Vigor de sementes, população de plantas e desempenho agronômico de soja. Revista de Ciências Agrárias, 60(3), 215-222. doi: 10.4322/rca.2239

Sangoi, L., Berns, A. C., Almeida, M. L., Zanin, C. G., \& Schweitzer, C. (2007). Características agronômicas de cultivares de trigo em resposta à época da adubação nitrogenada de cobertura. Ciência Rural, 37(6), 1564-1580. doi: 10.1590/S010384782007000600010

Sbrussi, C. A. G., \& Zucareli, C. (2014). Germinação de sementes de milho com diferentes níveis de vigor em resposta à diferentes temperaturas. Semina: Ciências Agrárias, 35(1), 215-226. doi: 10.5433/1679-0359.2014v35n1p215

Silva, R. R., Benin, G., Silva, G. O., Marchioro, V. S., Almeida, J. L., \& Matei, G. (2011). Adaptabilidade e estabilidade de cultivares de trigo em diferentes épocas de semeadura, no Paraná. Pesquisa Agropecuária Brasileira, 46(11), 1439-1447. doi: 10.1590/S0100204X2011001100004

Silva, S. R., Bassoi, M. C., \& Foloni, J. S. S. (2018). Informações técnicas para trigo e triticale - safra 2019. Reunião da Comissão Brasileira de Pesquisa de Trigo e Triticale. Brasília: EMBRAPA. Recuperado de https://www.embrapa.br/en/busca-depublicacoes/-/publicacao/1108443/ informacoes-tecnicas-para-trigo-etriticale---safra-2019
Taiz, L., Zeiger, E., Moller, I. M., \& Murphy, A. (2017). Fisiologia e desenvolvimento vegetal (6a ed.). Lavras: Artmed.

Tavares, L. C. V., Foloni, J. S. S., Bassoi, M. C., \& Prete, C. E. C. (2014). Genótipos de trigo em diferentes densidades de semeadura. Pesquisa Agropecuária Tropical, 44(2), 166-174. doi: 10.1590/S1983-40632014 000200010

Teixeira, M. C. M., Fo., Buzetti, S., Andreotti, M., Arf, O., \& Benett, C. G. S. (2010). Doses, fontes e épocas de aplicação de nitrogênio em trigo irrigado em plantio direto. Pesquisa Agropecuária Brasileira, 45(8), 797-804. doi: 10.1590/S0100-204X 2010000800004

United States Department of Agriculture (2020). World agricultural production. Retrieved from https://apps. fas.usda.gov/ psdonline/circulars/production.pdf

Yan, W., \& Holland, J. B. (2010). A heritability adjusted GGE biplot for test environment evaluation. Euphytica, 171(3), 355-369. doi: 10.1007/s10681-009-0030-5 
